\title{
Improving Student Learning Outcomes On Theme 3 My Activities Through Media Power Point In Sd Negeri Sampang 01
}

\author{
Dahlia Ratna Kusuma Astuti \\ SD Negeri Sampang 01 \\ dahlia.ratna.kusuma.astuti@gmail.com
}

\section{Article History}

accepted 14/11/2020

approved $21 / 11 / 2020$

published 26/11/2020

\begin{abstract}
In the initial study of Tema 3 Kegiatanku, showed low interest and understanding of the material. If this is left it will have a negative impact on the next learning. To solve the problem, researchers made improvements to learning using power point media. Improvement of learning conducted by researchers aims to: (1) Improve the learning results of grade I students of Sampang State Elementary School 01 Sampang sub-district on the theme of 3 My Activities. (2) Applying media power points to improve the learning results of grade I students of Sampang State Elementary School 01 on the theme of 3 My Activities. Learning improvement research is carried out through two cycles, each cycle consisting of the stage of planning, performing actions, observing, and reflection. Cycle I was implemented on November 2 and 3, 2020 and cycle II was implemented on November 9 and 10, 2020. After the improvement of learning, the completeness of students' learning outcomes improved. In the initial study, of the 24 students who achieved completeness only 14 students (58.3\%); after the first cycle, student learning results increased to 17 students (70.8\%) who ate accomplished; after cycle II, completed study results reached 20 students (83.3\%). Based on the data can be concluded that the use of power point media on the theme of 3 Kegiatanku can improve the learning results of grade I students of Sampang State Elementary School 01
\end{abstract}

Keywords: Learning outcomes, Learning Media, Power point

\begin{abstract}
Abstrak
Pada studi awal pembelajaran Tema 3 Kegiatanku, menunjukan rendahnya minat dan pemahaman siswa terhadap materi tersebut. Jika hal ini dibiarkan akan berdampak negative terhadap pembelajaran berikutnya. Untuk mengatasi masalah tersebut, peneliti melakukan perbaikan pembelajaran dengan menggunakan media power point. Perbaikan pembelajaran dilakukan peneliti bertujuan untuk: (1) Meningkatkan hasil belajar siswa kelas I SD Negeri Sampang 01 Kecamatan Sampang pada tema 3 Kegiatanku. (2) Menerapkan media power point untuk meningkatkan hasil belajar siswa kelas I SD Negeri Sampang 01 pada tema 3 Kegiatanku. Penelitian perbaikan pembelajaran dilaksanakan melalui dua siklus, yang setiap siklus terdiri dari tahap merencanakan, melakukan tindakan, mengamati, dan refleksi. Siklus I dilaksanakan pada tanggal 2 dan 3 November 2020 dan siklus II dilaksanakan pada tanggal 9 dan 10 November 2020. Setelah dilaksanakan perbaikan pembelajaran, ketuntasan hasil belajar siswa mengalami peningkatan. Pada studi awal pembelajaran, dari 24 siswa yang mencapai ketuntasan hanya 14 siswa $(58,3 \%)$; setelah dilaksanakan siklus I, hasil belajar siswa meningkat menjadi 17 siswa $(70,8 \%)$ yang mencapai ketuntasan; setelah siklus II, hasil belajar yang tuntas mencapai 20 siswa $(83,3 \%)$. Berdasarkan data tersebut dapat disimpulkan bahwa penggunaan media power point pada tema 3 Kegiatanku dapat meningkatkan hasil belajar siswa kelas I SD Negeri Sampang 01
\end{abstract}

Kata kunci: Hasil belajar, Media Pembelajaran, Power point

Social, Humanities, and Education Studies (SHEs): Conference Series https://jurnal.uns.ac.id/shes

p-ISSN 2620-9284

e-ISSN 2620-9292 


\section{PENDAHULUAN}

Pendidikan merupakan salah satu tolak ukur bagi kemajuan suatu bangsa. Dengan pendidikan, sumber daya manusia dapat dibangun, kecerdasan bangsa dapat ditingkatkan dan kesejahteraan juga dapat dirasakan oleh seluruh lapisan masyarakat. Pendidikan dapat dijadikan sebagai kata kunci yang pokok untuk menilai kemajuan suatu bangsa. Peningkatan mutu pendidikan sekarang terus menjadi perhatian dari beberapa pihak, khususnya pendidikan Sekolah Dasar. Apalagi untuk tahun sekarang pendidikan menggunakan sistem Kurikulum 2013 yang dimana semua muatan pelajaran saling terintegrasi dan berkesinambungan.

Seiring berjalannya waktu, peneliti telah melaksanakan pembelajaran di dalam kelas I semester I tahun pelajaran 2020/2021 dengan mata pelajaran sesuai dengan kurikulum 2013 yang bertumpu pada Kriteria Ketuntasan Minimal (KKM) yang telah ditentukan oleh sekolah. Peneliti dalam melaksanakan pembelajaran di kelas I telah memberikan pembelajaran yang dilanjutkan dengan memberikan soal setiap pembelajaran yang telah peneliti laksanakan. Hal ini dimaksud agar peneliti dapat melihat daya serap siswa dalam menerima pembelajaran yang disampaikan oleh guru di dalam kelas.

Berdasarkan dokumen yang diperoleh dari siswa kelas I SD Negeri Sampang 01 sebagai berikut: dari 24 siswa; hanya 14 siswa (58,3\%) yang memenuhi KKM, dan 10 siswa $(41,7 \%)$ belum memenuhu KKM (70), ini berarti KKM belum tuntas, karena KKM dianggap tuntas apabila persentase nilai siswa yang mencapai KKM adalah $90 \%$ dari jumlah siswa.

Berdasarkan data tersebut rendahnya nilai hasil belajar disebabkan karena sebagian siswa yang bosan, kurang fokus dan kurang aktif dalam pembelajaran. Meskipun masih kurang paham terhadap penjelasan guru namun siswa terlihat pasif sehingga dalam pembelajaran peran guru lebih dominan.

Upaya untuk lebih meningkatkan keberhasilan pembelajaran siswa sangatlah diperlukan., diantaranya dengan memperbaiki proses pembelajaran. Dalam perbaikan proses pembelajaran ini, peran guru dinilai sangat penting yaitu dimana guru harus mampu menentukan metode dan media yang tepat dalam pembelajaran. Hal ini dimaksudkan agar materi tersebut dapat dipahami oleh siswa kelas I SD Negeri Sampang 01 Kecamatan Sampang Kabupaten Cilacap.

Berdasarkan uraian di atas, maka peneliti ingin melakukan penelitian lebih lanjut dengan judul "Meningkatkan Hasil Belajar Siswa pada Tema 3 Kegiatanku Melalui Media Power Point di SD Negeri Sampang 01 Kelas 1 Semester 1 Tahun Pelajaran 2020/2021"

Menurut Hamalik (2002) hasil belajar diartikan sebagai tingkat keberhasilan siswa dalam mempelajari materi pelajaran di sekolah, yang dinyatakan dalam bentuk skor yang diperoleh dari hasil tes mengenai sejumlah materi pelajaran tertentu. Ada dua faktor yang mempengaruhi hasil belajar yang diperoleh oleh siswa yakni faktor dari dalam diri siswaitu dan faktor datang dari luar diri siswa atau faktor lingkungan. Faktor kemampuan siswa besar sekali pengaruhnya terhadap hasil belajar yang dicapai. Hasil belajar siswa $70 \%$ dipengaruhi oleh kemampuan siswa dan $30 \%$ dipengaruhi oleh lingkungan.

Menurut Nana Sudjana (2008) mengemukakan penilaian hasil belajar mengisyaratkan bahwa hasil belajar sebagai objek yang menjadi sasaran penilaian. Hasil belajar sebagai objek penilaian pada hakikatnya menilai penguasaan siswa terhadap tujuan-tujuan intruksional, karena rumusan tujuan intruksional menggambarkan hasil belajar yang harus dikuasai siswa berupa kemampuankemampuan siswa setelah menerima atau menyelesaikan pengalaman belajarnya. Hasil belajar sebagai objek penilaian pada hakikatnya menilai penguasaan siswa terhadap tujuan-tujuan intruksional, karena rumusan tujuan intruksional 
menggambarkan hasil belajar yang harus dikuasai siswa berupa kemampuankemampuan siswa setelah menerima atau menyelesaikan pengalaman belajarnya.

Seiring dengan definisi-definisi hasil belajar menurut para ahli, Gagne (dalam Asep Heri Hernawan, 2009) mengelompokkan hasil belajar ke dalam lima kategori yaitu, informasi verbal, keterampilan intelektual, strategi kognitif, sikap, dan keterampilan motorik. Sedangkan Bloom, dkk (dalam Asep Heri Hernawan, 2009) menggolongkan hasil belajar menjadi tiga, yaitu kognitif, afektif, dan psikomotor. Seperti yang sudah dikemukakan oleh para ahli di atas, peneliti beranggapan bahwa hasil belajar merupakan hasil atau tanda bukti yang diperoleh siswa selama pembelajaran yang berguna untuk mengukur kemampuan siswa.

Beberapa faktor yang memengaruhi hasil belajar menurut Sri Anitah W (2011: 2.7) adalah "faktor dari dalam diri siswa yang berpengaruh terhadap hasil belajar diantaranya adalah kecakapan, minat bakat, usaha, motivasi, perhatian, kelemahan, dan keseharaan, serta kebiasaan siswa." Salah satu hal penting dalam belajar berkitan dengan seberapa besar individu merasa suka atau tidak suka terhadap suatu materi yang dipelajari siswa. Minat, motivasi, dan perhatian siswa dapat dikondisikan oleh guru. Setiap individu memiliki kecakapan (ability) yang berbeda-beda. Kecakapan tersebut daapt dikelompokan berdasarkan kecepatan belajar, yakni sangat cepat, sedang, dan lambat. Demikian pula pengelompokan kemampuan siswa berdasarkan kemampuan penerimaannya, misalnya proses pemahamannya harud dengan cara perantara visual, verbal, dan atau harus dibantu dengan alat/media. Faktor dari luar diri siswa yang mempengaruhi hasil belajar diantaranya adalah lingkungan fisik dan non fisik (termasuk suasan kelas dalam belajar, seperti riang gembira, menyenangkan), lingkungan sosial budaya, lingkungan keluarga, program sekolah (termasuk dukungan komite sekolah), guru pelaksanaan pembelajaran, teman sekolah". Dari penjelasan ahli di atas, peneliti menilai peran guru dalam hal ini merupakan sebagai sutradara di dalam kelas. Di sini guru dituntut mempunyai kompetensi dasar yang syaratkan dalam profesi guru.

Media adalah segala bentuk dan saluran yang digunakan untuk menyampaikan informasi atau pesan. Kata media berasal dari kata latin, merupakan bentuk jamak dari kata "medium". Secara harfiah kata tersebut mempunyai arti "perantara" atau "pengantar", yaitu perantara sumber pesan (a source) dengan penerima pesan (a receiver). Jadi, dalam pengertian yang lain, media adalah alat atau sarana yang dipergunakan untuk menyampaikan pesan.

Microsoft powerpoint adalah salah satu aplikasi yang terdapat dalam Microsoft office yang menawarkan berbagai macam fitur yang dibutuhkan untuk keperluan presentasi. Jika zaman dahulu orang-orang menggunakan presentasi transparan dengan proyektor sebagai alatnya, sekarang telah digantikan oleh Microsoft powerpoint yang jauh lebih menarik ketika digunakan untuk presentasi.

Salah satu fitur yang terdapat pada Microsoft powerpoint adalah template. Template ini dapat anda gunakan sebagai background presentasi yang fungsinya untuk mempercantik tampilan presentasi anda. Selain fitur diatas, penyimpanan file presentasi power point anda pun dapat anda lakukan dalam berbagai format, mulai dari PPT, PPS, POT dan PPTX.

Penelitian ini memiliki beberapa tujuan antara lain: meningkatkan hasil belajar siswa kelas I SD Negeri Sampang 01 Kecamatan Sampang pada tema 3 Kegiatanku; menerapka media power point untuk meningkatkan hasil belajar siswa kelas I SD Negeri Sampang 01 pada Tema 3 Kegiatanku; untuk memenuhi tugas Pendidikan Profesi Guru (PPG) Dalam Jabatan Angkatan 3 Tahun 2020 Universitas Sebelas Maret, Surakarta. 


\section{METODE}

Penelitian Tindakan Kelas (PTK) yang digunakan peneliti adalah jenis PTK kolaboratif. PTK kolaboratif yaitu kerja sama antara peneliti dengan teman sejawat, ide berasal dari peneliti dan yang melakukan tindakan adalah guru kelas I A1 SD Negeri Sampang 01 di lakukan pada semester I. Unit penelitian adalah kelas I A1 SD Negeri Sampang 01. Penelitian ini dilaksanakan pada semester I tahun pelajaran 2020/2021. Subjek dalam penelitian ini adalah siswa kelas I A1 SD Negeri Sampang 01 Kecamatan Sampang Kabupaten Cilacap Jawa Tengah dengan jumlah siswa 24 anak. Teknik pengumpulan data yang digunakan oleh peneliti adalah sebagai berikut: Data proses pembelajaran diperoleh dengan menggunakan lembar observasi selama pelaksanaan perbaikan pembelajaran. Data hasil belajar siswa diperoleh dengan mengadakan tes formatif. Data keterkaitan antara perencanaan dan pelaksanaan perbaikan pembelajaran diperoleh dari RPP dan lembar observasi. Hasil dari pengumpulan data di atas, mulai dari data proses pembelajaran sampai data keterkaitan dianalisis untuk mencari alternatif pemecahan pada perbaikan pembelajaran berikutnya. Teknik yang peneliti terapkan pada proses pembelajaran Penelitian Tindakan Kelas pada Kelas I SD Negeri Sampang 01 kecamatan Sampang tema 3 Kegiatanku dengan melalui media powerponit adalah dengan membandingkan hasil belajar yang diperoleh pada siklus 1, siklus 2, dan siklus 3 . Jika hasil yang diperoleh belum mencapai hasil yang diharapkan peneliti yaitu siswa yang mencapai nilai Kriteria Ketuntasan Minimal (KKM) mencapai 90\% dari jumlah siswa, maka akan dilakukan kembali perbaikan pembelajaran sampai memenuhi kriteria keberhasilan yang terlah ditentukan.

\section{HASIL DAN PEMBAHASAN}

Penelitian yang telah dilakukan akhirnya diperoleh data-data yang dapat diuraikan sebagai berikut: Kegiatan yang dilakukan dalam tahapan ini adalah menyiapkan segala sesuatu yang diperlukan dalam melaksanakan skenario pembelajaran siklus I yang telah direncanakan. Kegiatan yang dilakukan antara lain: Membuat Rencana Pelaksanaan Pembelajaran (RPP) dengan materi Tema 3 Kegiatanku. Menyiapkan lembar observasi (pengamatan) sebagai pedoman atas proses pembelajaran menggunakan video powerpoint. Menyusun soal tes untuk menilai peningkatan hasil belajar siswa terhadap materi yang diajarkan.

Pelaksanaan tindakan dilakukan 2 kali yaitu pada tanggal 2 dan 3 Nopember 2020. Deskripsi pelaksanaan tindakan pembelajaran adalah sebagai berikut :Pertemuan Pertama. Kegiatan pembelajaran diawali oleh guru mengucapkan salam, dilanjutkan peserta didik menjawab salam dengan serempak. Guru meminta salah satu peserta didik untuk memimpin do'a, setelah itu dilanjutkan dengan mengabsen peserta didik dilanjutkan dengan mengingatkan tentang protocol kesehatan covid-19. Kemudian guru memberikan motivasi dengan mengajak peserta didik untuk menyanyikan lagu "Halo-Halo Bandung". Setelah itu guru mulai membuka pelajaran dengan mencoba mengingatkan kembali materi sebelumnya dan menyampaikan tentang tujuan pembelajaran. Guru mulai masuk kedalam kegiatan pembelajaran. Guru bersama siswa belajar dengan media pembelajaran berupa Ms.Power Point dan dijelaskan ke siswa. Guru menjelaskan materi melalui Power Point yang di share screen melalui zoom. Siswa diminta untuk mencermati teks percakapan tentang permintaan tolong dilanjutkan dengan memperagakan teks percakapan tersebut. Kemudian guru dan siswa melakukan tanya jawab terkait teks percakapan tersebut. Guru memberi penguatan. Siswa diminta untuk mendownload LKPD I yang ada di google drive dan mengerjakannya, diupload kembali pada WhatsApp Grup. Kemudian, guru mengaitkan ungkapan permintaan tolong dengan perilaku yang sesuai dengan nilai-nilai Pancasila. Siswa menganalisis beberapa kegiatan yang sesuai dengan nilai- 
nilai Pancasila. Siswa mengamati penjelasan guru. Setelah itu, guru dan siswa melakukan tanya jawab. Guru memberi penguatan. Siswa diminta untuk mendownload LKPD II yang ada di google drive dan mengerjakannya, diupload kembali pada WhatsApp Grup.. Guru.melanjutkan menjelaskan meteri berikutnya. Sebelum mengakhiri pembelajaran guru mengingatkan pada peserta didik bahwa pada pertemuan berikutnya akan diadakan ulangan atau evaluasi dengan materi yang telah diajarkan. Setelah itu guru mengakhiri pelajaran dengan salam dan dijawab serempak oleh peserta didik.

Pertemuan kedua. Guru mengawali pelajaran dengan salam, peserta didik menjawab serempak. Guru meminta salah satu siswa memimpin do'a, setelah selesai, guru mengabsen peserta didik. Guru mulai masuk kedalam kegiatan pembelajaran. Guru bersama siswa belajar dengan media pembelajaran berupa Ms.Power Point. Guru menjelaskan materi melalui Power Point yang di share screen melalui Zoom. Guru mengarahkan siswa untuk mondownload LKPD III. Siswa diminta mengerjakan LKPD tersebut dan mengupload kembali pada WhatsApp Grup. Guru memberikan kesempatan kepada siswa untuk bertanya tentang materi yang belum dipahami. Guru meminta siswa untuk mengerjakan evaluasi melalui google form yang di share melalui WhatsApp Grup. Pada evaluasi siklus I diikuti oleh semua peserta didik kelas I, yakni sebanyak 24 peserta didik. Peserta didik diberi waktu 60 menit untuk mengerjakan soal evaluasi melalui google form yang linknya tercantum pada WhatsApp Grup. Guru mengakhiri pelajaran dengan salam.

Berdasarkan latar belakang penelitian ini, hasil pembelajaran tema 3 pada siswa kelas I A1 yang berjumlah 24 siswa, sebelum menggunakan media berupa power point, rata - rata yang diperoleh adalah 70,4 . Siswa yang mencapai KKM adalah $58,3 \%$ dan siswa yang belum mencapai $\mathrm{KKM}$ adalah $41,7 \%$, sehingga dapat diartikan KKM belum tuntas, karena KKM dianggap tuntas adalah jika mencapai minimal $90 \%$.

Hasil observasi yang dilakukan oleh observer selama jalannya kegiatan pembelajaran dan mengamati hasil evaluasi pada akhir kegiatan siklus pertama belum berhasil karena siswa yang tuntas hanya 17 siswa dari 24 siswa. Siswa yang sudah tuntas baru mencapai 70,8\%.

Hasil belajar pada siklus I mengalami peningkatan dibandingkan dengan keadaan awal yang disajikan pada latar belakang masalah. Hasil tes awal siswa yang tuntas mencapai $58,3 \%$, sedangkan pada hasil evaluasi siklus I siswa yang tuntas mencapai $70,8 \%$. Hal ini menunjukkan ada peningkatan hasil belajar siswa sebesar $12,5 \%$. Dari deskripsi di atas menunjukkan bahwa hasil rata-rata kelas meningkat pada siklus I, namun belum dikatakan berhasil dalam pembelajaran Tema 3 karena siswa yang tuntas (KKM) belum mencapai 90\%. Berdasarkan hal tersebut, maka masih diperlukan perbaikan pembelajaran dengan media yang sama pada Siklus II. Berdasarkan hasil tes awal dan evaluasi siklus 1 tersebut, dapat dilihat presentase ketuntasan belajar siklus 1 sebagai berikut :

Tabel 1. Persentase Ketuntasan Belajar Siklus I

\begin{tabular}{|c|c|c|c|c|c|}
\hline \multirow[b]{2}{*}{ No } & \multirow[b]{2}{*}{ Uraian } & \multicolumn{2}{|c|}{ Siswa yang Tuntas } & \multicolumn{2}{|c|}{ Siswa Belum Tuntas } \\
\hline & & Frekuensi & Persentase & Frekunsi & Persentase \\
\hline 1 & $\begin{array}{l}\text { Kondisi Awal (sesuai } \\
\text { dengan keadaan pada latar } \\
\text { belakang) }\end{array}$ & 14 & $58,3 \%$ & 10 & $41,7 \%$ \\
\hline 2 & Siklus I & 17 & $70,8 \%$ & 7 & $29,2 \%$ \\
\hline
\end{tabular}


Tabel di atas dapat dijelaskan siswa yang belum tuntas belajar adalah sebagai berikut: Pada kondisi awal sesuai dengan latar belakang penelitian, siswa yang belum tuntas sebanyak 10 siswa dari 24 siswa atau 41,7\%. Pada siklus 1, siswa yang belum tuntas sebanyak 7 siswa dari 24 siswa atau 29,2\%. Sedangkan siswa yang tuntas belajar adalah sebagai berikut : Pada kondisi awal sesuai dengan latar belakang penelitian, siswa yang tuntas sebanyak 14 siswa dari 24 siswa atau 58,3\%. Pada siklus 1, siswa yang tuntas sebanyak 17 siswa dari 24 siswa atau $70,8 \%$.

Berdasarkan tabel diatas dapat dibuat diagram batang hasil belajar siklus 1 sebagai berikut :

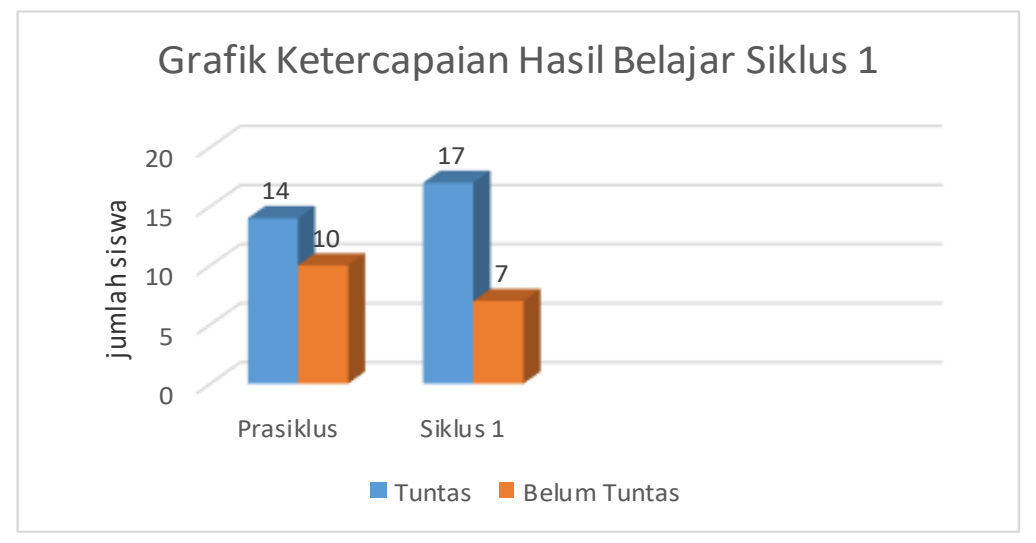

\section{Gambar 1. Grafik ketercapaian hasil belajar siklus I}

Penelitian yang telah dilakukan akhirnya diperoleh data-data yang dapat diuraikan sebagai berikut:

Perencanaan Penelitian

Kegiatan yang dilakukan dalam tahapan ini adalah menyiapkan segala sesuatu yang diperlukan dalam melaksanakan skenario pembelajaran siklus I yang telah direncanakan. Kegiatan yang dilakukan antara lain: Membuat Rencana Pelaksanaan Pembelajaran (RPP) dengan materi Tema 3 Kegiatanku. Menyiapkan lembar observasi (pengamatan) sebagai pedoman atas proses pembelajaran menggunakan video powerpoint. Menyusun soal tes untuk menilai peningkatan hasil belajar siswa terhadap materi yang diajarkan.

Pelaksanaan tindakan dilakukan 2 kali yaitu pada tanggal 9 dan 10 Nopember 2020. Deskripsi pelaksanaan tindakan pembelajaran adalah sebagai berikut : Pertemuan Pertama. Kegiatan pembelajaran diawali oleh guru mengucapkan salam, dilanjutkan peserta didik menjawab salam dengan serempak. Guru meminta salah satu peserta didik untuk memimpin do'a, setelah itu dilanjutkan dengan mengabsen peserta didik dilanjutkan dengan mengingatkan tentang protocol kesehatan covid-19. Kemudian guru memberikan motivasi dengan mengajak peserta didik untuk menyanyikan lagu "Garuda Pancasila". Setelah itu guru mulai membuka pelajaran dengan mencoba mengingatkan kembali materi sebelumnya dan menyampaikan tentang tujuan pembelajaran. Guru mulai masuk kedalam kegiatan pembelajaran. Guru bersama siswa belajar dengan media pembelajaran berupa Ms.Power Point dan dijelaskan ke siswa. Guru menjelaskan materi melalui Power Point yang di share screen melalui zoom. Siswa diminta untuk mencermati teks bacaan tentang malam hari. Kemudian guru dan siswa melakukan tanya jawab terkait teks bacaan tersebut. Guru memberi penguatan. Siswa diminta untuk mendownload LKPD I yang ada di google drive dan mengerjakannya, diupload kembali pada WhatsApp Grup. Kemudian, guru mengaitkan suasana malam hari dengan kegiatan yang dapat dilakukan di malam hari. Siswa menganalisis beberapa kegiatan yang dapat dilakukan di malam hari yang sesuai dengan aturan di rumah. Siswa mengamati penjelasan guru. Setelah itu, guru 
dan siswa melakukan tanya jawab. Guru memberi penguatan. Siswa diminta untuk mendownload LKPD II yang ada di google drive dan mengerjakannya, diupload kembali pada WhatsApp Grup. Guru melanjutkan menjelaskan meteri berikutnya. Sebelum mengakhiri pembelajaran guru mengingatkan pada peserta didik bahwa pada pertemuan berikutnya akan diadakan ulangan atau evaluasi dengan materi yang telah diajarkan. Setelah itu guru mengakhiri pelajaran dengan salam dan dijawab serempak oleh peserta didikPertemuan kedua.

Pertemuan kedua. Guru mengawali pelajaran dengan salam, peserta didik menjawab serempak. Guru meminta salah satu siswa memimpin do'a, setelah selesai, guru mengabsen peserta didik. Guru mulai masuk kedalam kegiatan pembelajaran. Guru bersama siswa belajar dengan media pembelajaran berupa Ms.Power Point. Guru menjelaskan materi melalui Power Point yang di share screen melalui Zoom. Guru mengarahkan siswa untuk mondownload LKPD III. Siswa diminta mengerjakan LKPD tersebut dan mengupload kembali pada WhatsApp Grup. Guru memberikan kesempatan kepada siswa untuk bertanya tentang materi yang belum dipahami. Guru meminta siswa untuk mengerjakan evaluasi melalui google form yang di share melalui WhatsApp Grup. Pada evaluasi siklus II diikuti oleh semua peserta didik kelas I, yakni sebanyak 24 peserta didik. Peserta didik diberi waktu 60 menit untuk mengerjakan soal evaluasi melalui google form yang linknya tercantum pada WhatsApp Grup. Guru mengakhiri pelajaran dengan salam.

Hasil observasi yang dilakukan oleh observer selama jalannya kegiatan pembelajaran dan mengamati hasil evaluasi pada akhir kegiatan siklus II bisa dikatakan belum berhasil karena siswa yang tuntas sebanyak 20 siswa dari 24 siswa dengan prosentase $83,3 \%$. Dengan kata lain siswa yang tuntas belum mencapai $90 \%$. Sehingga perlu diadakan kembali perbaikan pembelajaran pada siklus III.

Hasil belajar pada siklus II mengalami peningkatan dibandingkan dengan siklus I. Hasil evaluasi siklus I siswa yang tuntas mencapai 70,8\%, sedangkan pada hasil evaluasi siklus II siswa yang tuntas mencapai $83,3 \%$. Hal ini menunjukkan ada peningkatan hasil belajar siswa sebesar 12,5\%. Dari deskripsi di atas menunjukkan bahwa hasil rata-rata kelas I meningkat pada siklus II walaupun dikatakan belum berhasil dalam pembelajaran Tema 3 karena siswa yang tuntas (KKM) belum mencapai $90 \%$. Meskipun demikian, masih diperlukan perbaikan pembelajaran dengan media yang sama pada siklus III.

Berdasarkan hasil evaluasi siklus II tersebut, dapat dilihat presentase ketuntasan belajar siklus II sebagai berikut :

Tabel 2. Persentase Ketuntasan Belajar Siklus II

\begin{tabular}{|c|l|c|c|c|c|}
\hline \multirow{2}{*}{ No } & \multicolumn{2}{|c|}{ Uraian } & \multicolumn{2}{c|}{ Siswa yang Tuntas } & \multicolumn{2}{c|}{ Siswa Belum Tuntas } \\
\cline { 3 - 6 } & \multicolumn{1}{|c|}{ Frekuensi } & Persentase & Frekunsi & Persentase \\
\hline 1 & $\begin{array}{l}\text { Kondisi Awal (sesuai } \\
\text { dengan keadaan pada } \\
\text { latar belakang) }\end{array}$ & 14 & $58,3 \%$ & 10 & $41,7 \%$ \\
\hline 2 & Siklus I & 17 & $70,8 \%$ & 7 & $29,2 \%$ \\
\hline 3 & Siklus II & 20 & $83,3 \%$ & 4 & $16,7 \%$ \\
\hline
\end{tabular}

Tabel di atas dapat dijelaskan siswa yang belum tuntas belajar adalah sebagai berikut : Pada kondisi awal sesuai dengan latar belakang penelitian, siswa yang belum tuntas sebanyak 10 siswa dari 24 siswa atau $41,7 \%$. Pada siklus I, siswa yang belum tuntas sebanyak 7 siswa dari 24 siswa atau $29,2 \%$. Pada siklus II, siswa yang belum 
tuntas sebanyak 4 siswa dari 24 siswa atau 16,7\%. Sedangkan siswa yang tuntas belajar adalah sebagai berikut. Pada kondisi awal sesuai dengan latar belakang penelitian, siswa yang tuntas sebanyak 14 siswa dari 24 siswa atau 58,3\%. Pada siklus I, siswa yang tuntas sebanyak 17 siswa dari 24 siswa atau 70,8\%. Pada siklus II, siswa yang tuntas sebanyak 20 siswa dari 24 siswa atau $83,3 \%$

Berdasarkan tabel diatas dapat dibuat diagram batang hasil belajar siklus II sebagai berikut :

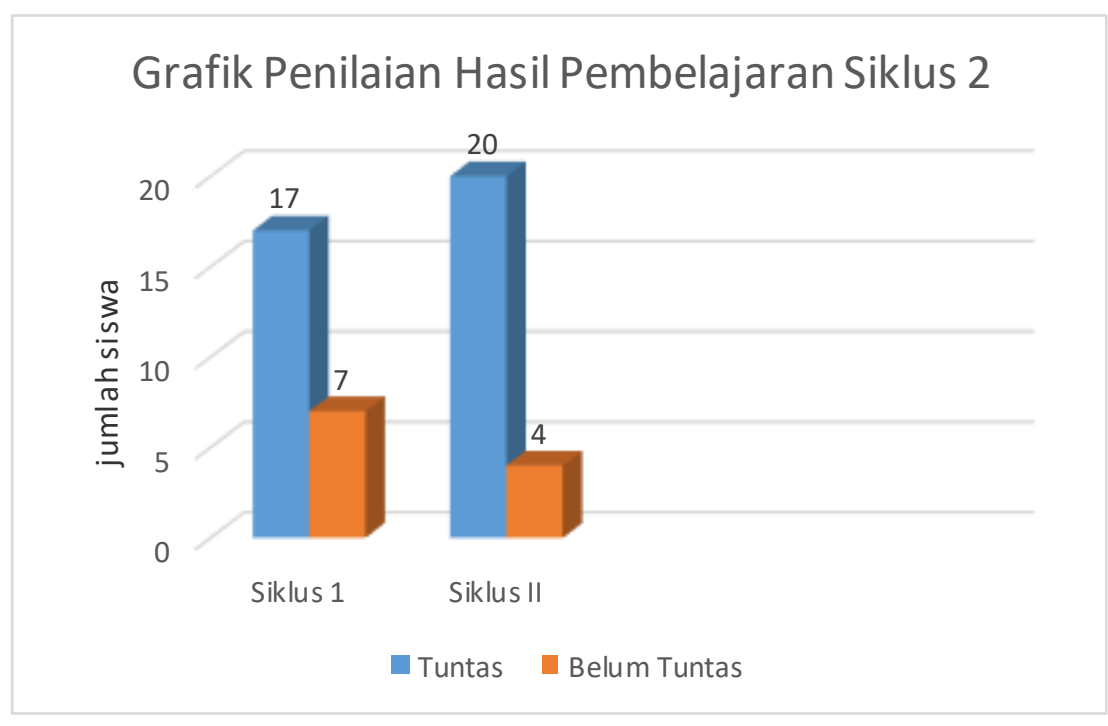

Gambar 2. Grafik hasil belajar siklus II

\section{SIMPULAN}

Penggunaan media powerpoint dapat meningkatkan hasil belajar siswa pada Tema 3 Kegiatanku kelas I SD Negeri Sampang 01, hal ini dibuktikan dari hasil belajar pada siklus I yaitu siswa yang belum tuntas sebanyak 7 siswa dari 24 siswa atau $29,2 \%$, sedangkan siswa yang tuntas sebanyak 17 siswa dari 24 siswa atau $70,8 \%$. Pada siklus II, Pada kondisi awal sesuai dengan latar belakang penelitian, siswa yang belum tuntas sebanyak 10 siswa dari 24 siswa atau 41,7\%. Pada siklus II, siswa yang belum tuntas sebanyak 4 siswa dari 24 siswa atau 16,7\%, sedangkan siswa yang tuntas sebanyak 20 siswa dari 24 siswa atau 83,3\%. Ini artinya hasil belajar siswa meningkat dari siklus I ke siklus II. Hendaknya guru mengembangkan pembelajaran menggunakan media powerpoint pada pelajaran yang lain. 


\section{DAFTAR PUSTAKA}

Anitah, Sri W, dkk. (2011). Strategi Pembelajaran di SD. Jakarta: Universitas Terbuka

Edi Subarkah (2020). Pengertian Microsof PowerPoint, Fungsi, dan Manfaatnya. Diunduh 21 Oktober 2020 dari https://www.belajaroffice.com/pengertianmicrosoft-powerpoint-fungsi-dan-manfaatnya/

Hamalik, Oemar. 2001. Proses Belajar Mengajar. Jakarta: Bumi Aksara.

Hernawan, Asep Heri, dkk. 2009. Pengembangan Kurikulum dan Pembelajaran. Jakarta: Universitas Terbuka.

Sudjana, Nana. 2008. Penilaian Hasil Proses Belajar Mangajar. Bandung: PT Remaja Rosdakarya.

Susilana, Rudi. Riyana, Cepi. 2009. Media Pembelajaran: Hakikat, Pengembangan, Pemanfaatan, dan Penilaian. Bandung: CV Wacana Prima. Diunduh 21 Oktober 2020 dari https://pengertianahli.id/pengertianmedia-dan-jenis-media/

Wardhani, IGAK dan Kuswaya Wihardit. 2012. Penelitian Tindakan Kelas. Tangerang Selatan: Universitas Terbuka

Wikipedia (2020). Pengertian Penelitian Tindakan Kelas. Diuduh 21 Oktober 2020 dari https://id.wikipedia.org/wiki/Penelitian_tindakan_kelas 